\title{
Effect of Gibberellic Acid, Naphthalenacetic Acid, Calcium and Zinc Spraying on Fruiting of Manfalouty Pomegranate Trees DrossMark
}

\author{
Masoud, A.A.B.; O.A. Khodair and Fatma El-Zahraa M. Gouda \\ ${ }^{1}$ Pomology Department, Fac. Agric, Assiut University \\ ${ }^{2}$ Horticulture Dept., Fac. Agric., Al-Azhar University, Assiut, Egypt. \\ *Email: Alaa.masoud@agr.aun.edu.eg
}

Received on: $24 / 2 / 2019$

Accepted for publication on: $3 / 3 / 2019$

\section{Abstract}

This study was carried out at the Experimental Orchard, Faculty of Agriculture, Assiut University, Egypt, to study the effect of Gibberellic Acid $\left(\mathrm{GA}_{3}\right)$, Naphthalenacetic acid (NAA), calcium chloride and zinc sulphate spraying on fruiting of Manfalouty pomegranate during 2017 and 2018 seasons. The experiment was set up in a complete randomized block design with three replicates, one tree per each.

$\mathrm{GA}_{3}$, NAA, calcium chloride $\left(\mathrm{CaCl}_{2}\right)$ and zinc sulphate $\left(\mathrm{ZnSO}_{4}\right)$ spraying significantly increased the yield/ tree compared to unsprayed ones. $\mathrm{GA}_{3}$ spraying gave the highest yield followed by calcium chloride. On the other hand, all treatments significantly decreased the fruit cracking percentage compared to unsprayed ones. The least fruit cracking was recorded due to calcium chloride spraying.

All treatments significantly increased fruit weight and fruit dimensions as well as pulp percentage and juice contents compared to unsprayed ones. Moreover, calcium chloride and zinc sulphate as well as combination of $\mathrm{GA}_{3}$ or NAA with them significantly improved the fruit chemical constituents, whereas, $\mathrm{GA}_{3}$ spraying alone decreased the chemical fruit constituents compared to unsprayed ones.

It could be concluded that spraying Manfalouty pomegranate trees with calcium chloride $\left(\mathrm{CaCl}_{2}\right)$ at $2 \%$ and zinc sulphate at $0.025 \%$ plus $\mathrm{GA}_{3}$ at $50 \mathrm{ppm}$ or NAA $25 \mathrm{ppm}$ thrice was necessary to get high yield, reduce the fruit cracking percentage and improve fruit quality.

Keywords: $\mathrm{GA}_{3}, \mathrm{NAA}$, Fruit cracking, Fruit quality, Manfalouty pomegranate.

Introduction

Pomegranate (Punica granatum) belongs to the family punicaceae and it is one of the favorite table fruits in the world. It is one of esteemed desert fruit and is very much liked by people for its cool refreshing juice, taste and being highly valued for its nutritional and medicinal properties (Singh, 2004 and Bakeer, 2016). Moreover, commercial pomegranate juice has been shown to have three times higher antioxidant activity than green tea and red wine (Gil et al., 2000). Pomegranate is one of the most suitable fruits for tropical, subtropical regions and even temperate regions (Sheikh and Manjula, 2012; Reddy and Prasad, 2012 and Bakeer, 2016).

In Egypt, the total cultivated area reached 10838 fed. and produced about 173007 ton (Ministry of Agriculture and Statistics, (M.A.L.R.) 2016). 
Manfalouty is considered one of the most important pomegranate cultivars grown successfully in upper Egypt (Hegazi et al., 2014).

The growth and development of fruit, yield and quality are generally poor due to non adoption of improved cultivation practices and several other horticultural practices. Among different elite horticultural practices, growth regulators have been advantageously used in the recent time to increase the fruit production and to improve the quality of several fruit crops.

Cracking causes a major fruits loss, which is a serious commercial loss to farmers. Fruit cracking, seems to be a problem that lessens the marketability to a great extent. This problem is due to the improper water management and deficiency of micronutrients and $\mathrm{Ca}$ (Sheikh and Manjula, 2012).

Calcium plays an important role in reducing fruit cracking, it improves fruit growth and creates a state of water balance between epicarp and inside fruit tissues, as well as maintains fruit cell wall elasticity and firmness (Mitra, 1997). Applying calcium before harvest improves various fruits quality (Pooviah, 1979 and Cheour et al, 1990).

Plant growth regulators enhance the rapid changes in physiological and biochemical characters and improve crop productivity. Plant growth regulators are reported to play a significant role in pomegranate productivity (Ghosh et al., 2009 and Anawal et al., 2016).

Spraying pomegranate with various concentrations of $\mathrm{GA}_{3}$ reduced the percentage of fruit cracking
(Sepahi, 1986; El-Salhy, 1996; Reddy and Prasad, 2012; Khalil and Aly, 2013; Hegazi et al., 2014; El-Akkad et al., 2016 and Masoud et al., 2018).

Zinc is an essential trace element for plants, being involved in many enzymatic reactions and is necessary for their good growth and development. It is also involved in regulating the protein and carbohydrate metabolism (Swietlik, 1999). Boron, zinc and calcium were highly effective in improving, nutritional status yield and fruit quality of pomegranate trees. Foliar application of some micronutrients such as $\mathrm{Fe}, \mathrm{B}, \mathrm{Mn}$ and $\mathrm{Zn}$ increased fruit yield and reduced the percentage of cracked fruits (Bambal et al., 1991; Bahadur et al., 1998 and Masoud et al., 2018).

So, this investigation aimed to study the effect of spraying with $\mathrm{GA}_{3}$, NAA, calcium chloride, and zinc sulphate on improving the fruiting of Manfalouty pomegranate cultivar.

\section{Materials and Methods}

This experiment was conducted at the Fruit Orchard of Faculty of Agriculture, Assiut University, Egypt during two successive seasons of 2017 and 2018. Thirty three healthy nearly uniformed in shapes, size and productivity pomegranate trees of Manfalouty cultivar, fourty one years old were chosen for this study. Trees are grown on clay soil and spaced $5 \times 5 \mathrm{~m}$ apart, subjected to surface irrigation system, and received the same horticultural practices.

This investigation included the following eleven treatments, as follow:

1- Control (spraying with water).

2- Spraying with gibberellic acid at $50 \mathrm{ppm}$ 
3- Spraying with gibberellic acid at $75 \mathrm{ppm}$

4- Spraying with Naphthalenacetic acid (NAA) at 25 ppm.

5- Spraying with NAA at 50 ppm.

6- Spraying with calcium chloride $\left(\mathrm{CaCl}_{2}\right)$ at $2 \%$.

7- Spraying with calcium chloride $\left(\mathrm{CaCl}_{2}\right)$ at $4 \%$.

8- Spraying with Zinc sulphate $(35 \% \mathrm{Zn})$ at $0.025 \%$.

9- Spraying with Zinc sulphate (35\% $\mathrm{Zn})$ at $0.050 \%$.

10 -Spraying with $\mathrm{GA}_{3} 50 \mathrm{ppm}+$ $\mathrm{CaCl}_{2} 2 \%+\mathrm{ZnSO}_{4} 0.025 \%$.

11-Spraying with NAA 25 ppm + $\mathrm{CaCl}_{2} 2 \%+\mathrm{ZnSO}_{4}$ 0.025\%

$\mathrm{GA}_{3}$, NAA, calcium chloride and $\mathrm{Zn}$ solution were prepared by dissolving the assigned amount in the required water. The trees received solutions with triton $\mathrm{B}, 0.1 \%$ as a surfactant to reduce surface tension and to facilitate the absorption of sprayed solution. Using a back held sprayers at the first and third week of May and second week of June during the two seasons of study.

The experiment was laid out in a complete randomized block design with eleven treatments each treatment replicated three times, one tree per each.

During both seasons, the following traits were measured: yield/tree $(\mathrm{kg})$, fruit cracking $(\%)$, fruit weight $(\mathrm{g})$, fruit dimension, pulp $(\%)$ and juice (\%) as well as total soluble solids (TSS), total acidity, TSS/acid ratio, reducing sugars and vitamin $\mathrm{C}$ content (ascorbic acid/100 $\mathrm{ml}$ juice) according to A.O.A.C. (1995). Total anthocyanin content of juice was determined according to
Rabino and Mancinelli (1986). Hydrolysable tannin content of juice was measured according to Cam and Hisil (2010).

Data were tabulated and statistically analyzed according to Snedecor and Cochran (1972). Means were compared using the least significant differences (New LSD) values at 5\% levels of the probability.

\section{Results}

\section{1- Yield and fruit cracking:}

Data presented in Table (1) showed the effect of $\mathrm{GA}_{3}, \mathrm{NAA}$, calcium chloride and Zinc sulphate spraying singly or combination on yield/tree and fruit cracking percentage of Manfalouty pomegranate trees during 2017 and 2018. It is obvious from the data that the results took similar trend during the two studied seasons.

In general view, data showed that all treatments significantly increased the yield/ tree compared to untreated ones. The highest values of yield/tree were recorded on the trees that sprayed by either $\mathrm{GA}_{3} 50 \mathrm{ppm}$ singly or combined with calcium chloride and zinc sulphate (103.64 \& $103.58 \mathrm{~kg}$ as an av. of the two studied seasons), respectively. On other hand, the lowest values were recorded on untreated trees $(84.07 \mathrm{~kg}$ as an av. of the two studied seasons). The obtained yield/tree were $(103.64$, $102.63,92.50,93.24,93.26,100.69$, $95.10,101.48,103.58,100.77$ and $84.07 \mathrm{~kg} /$ tree as an av. of the two studied season) due to spray with $\mathrm{GA}_{3}$ at $50 \mathrm{ppm}, \mathrm{GA}_{3}$ at $75 \mathrm{ppm}, \mathrm{NAA}$ $25 \mathrm{ppm}, \mathrm{NAA} 50 \mathrm{ppm} \mathrm{CaCl}_{2}$ at $2 \%$, $\mathrm{CaCl}_{2}$ at $4 \%, \mathrm{ZnSO}_{4} 0.025 \%, \mathrm{ZnSO}_{4}$ $0.050 \%, \mathrm{GA}_{3} 50$ ppm plus $\mathrm{CaCl}_{2} 2 \%$ and $\mathrm{ZnSO}_{4} 0.025 \%$, NAA 25 ppm 
plus $\mathrm{CaCl}_{2} 2 \%$ and $\mathrm{ZnSO}_{4} \quad 0.025 \%$ and untreated one (control).

Hence, the corresponding increment percentage over unsprayed ones were $(23,28,22.08,10.03$, $10.91,10.93,19.77,13.12,20.71$, 23.21 and $19.86 \%$, respectively).

Contrarly, all treatments significantly decreased the fruit cracking percentage compared to unsprayed ones. The least values was recoded on the trees that sprayed by $\mathrm{CaCl}_{2}$ at $2 \%$ (5.8 \& 5.4\%), whereas, the highest ones were obtained on unsprayed ones (15.3 \& 14.1\%) during the two studied seasons, respectively. The recorded fruit cracking percentage was (7.7, 6.5, 8.6, 8.1, 5.6, 6.0, 8.2, 7.5, $6.1,6.4$ and $14.7 \%$ as an av. of the two studied season) due to spray with $\mathrm{GA}_{3}$ at $50 \mathrm{ppm}, \mathrm{GA}_{3}$ at $75 \mathrm{ppm}, \mathrm{NAA}$ 25 , NAA $50, \mathrm{CaCl}_{2}$ at $2 \%, \mathrm{CaCl}_{2}$ at $4 \%, \mathrm{ZnSO}_{4} \quad 0.025 \%, \mathrm{ZnSO}_{4} \quad 0.050 \%$, $\mathrm{GA}_{3} 50 \mathrm{ppm}$ combined with $\mathrm{CaCl}_{2}$ $2 \%$ plus $\mathrm{ZnSO}_{4} 0.025 \%$, NAA 25 ppm combined $\mathrm{CaCl}_{2} 2 \%$ plus $\mathrm{ZnSO}_{4}$ $0.025 \%$ unsprayed one, respectively. Hence, the corresponding decrement percentage of fruit cracking percentage under unsprayed ones was at- tained $(47.62,55.78,41.50,44.89$, $61.90,59.18,44.22,48.98,58.50$ and $56.45 \%$ ), respectively.

\section{2- Fruit properties:}

\section{A- Physical fruit properties:}

These include fruit weight, fruit dimension, pulp percentage and juice percentage. As shown in Tables $(1 \&$ 2 ), fruit weight and its dimension took similar trend in response to different treatments. Generally, the results indicated that all treatments significantly increased all the studied physical fruit properties compared to untreated ones. Increasing concentrations of $\mathrm{GA}_{3}, \mathrm{CaCl}_{2}$ or $\mathrm{ZnsO}_{4}$ solution failed significantly effected on these fruit traits. Also, no significant differences were seen due to spray $\mathrm{GA}_{3}$, $\mathrm{CaCl}_{2}$ and combined of $\mathrm{GA}_{3}$ plus $\mathrm{CaCl}_{2}$ and zinc sulphate. $\mathrm{GA}_{3}$ at 50 ppm singly or combined with $\mathrm{CaCl}_{2}$ $2 \%$ and $\mathrm{ZnSO}_{4} \quad 0.025 \%$ gave the highest values of these traits, where the fruit weight reached $(456.2 \&$ $464.5 \mathrm{~g})$, pulp \% (65.62 \& $65.90 \%)$ and juice percentage $(49.71 \&$ $50.80 \%$ as an av. of the two studied seasons), respectively.

Table 1. Effect of $\mathrm{GA}_{3}$, NAA, calcium chloride and $\mathrm{Zn}$ spraying on yield/tree, fruit cracking, fruit weight (g) and pulp (\%) of Manfalouty pomegranate during 2017 and 2018 seasons.

\begin{tabular}{|c|c|c|c|c|c|c|c|c|c|c|c|c|}
\hline \multirow{2}{*}{ Treatment } & \multicolumn{3}{|c|}{ Yield kg/tree } & \multicolumn{3}{|c|}{ Fruit cracking (\%) } & \multicolumn{3}{|c|}{ Fruit weight (g) } & \multicolumn{3}{|c|}{ Pulp (\%) } \\
\hline & 2017 & 2018 & Mean & 2017 & 2018 & Mean & 2017 & 2018 & Mean & 2017 & 2018 & Mean \\
\hline Control & 79.84 & 88.30 & 84.07 & 15.3 & 14.1 & 14.7 & 383.2 & 358.3 & 370.8 & 60.11 & 59.82 & 59.97 \\
\hline $\mathbf{G A}_{3} \mathbf{5 0} \mathrm{ppm}$ & 99.18 & 108.11 & 103.64 & 8.2 & 7.8 & 7.7 & 481.8 & 430.6 & 456.2 & 66.35 & 64.89 & 65.62 \\
\hline $\mathrm{GA}_{3} 75 \mathrm{ppm}$ & 97.85 & 107.40 & 102.63 & 6.8 & 6.2 & 6.5 & 465.3 & 440.5 & 452.9 & 65.38 & 65.11 & 65.25 \\
\hline NAA 25 ppm & 86.90 & 98.10 & 92.50 & 9.2 & 8.0 & 8.6 & 408.9 & 402.0 & 405.5 & 65.66 & 64.11 & 64.88 \\
\hline NAA 50 ppm & 87.23 & 99.25 & 93.24 & 8.4 & 7.7 & 8.1 & 412.8 & 400.0 & 406.4 & 66.30 & 65.32 & 65.81 \\
\hline $\mathrm{CaCl} 2 \%$ & 87.68 & 98.83 & 93.26 & 5.8 & 5.4 & 5.6 & 453.0 & 436.8 & 444.9 & 64.80 & 65.16 & 64.98 \\
\hline $\mathrm{CaCl}$ & 95.80 & 105.58 & 100.69 & 6.1 & 5.8 & 6.0 & 446.0 & 451.2 & 448.6 & 65.90 & 64.18 & 65.04 \\
\hline Zn $0.025 \%$ & 89.68 & 100.53 & 95.10 & 8.5 & 7.9 & 8.2 & 415.0 & 422.0 & 418.5 & 65.84 & 65.00 & 65.42 \\
\hline Zn $0.050 \%$ & 96.72 & 106.23 & 101.48 & 7.9 & 7.1 & 7.5 & 423.0 & 418.5 & 420.8 & 66.30 & 64.84 & 65.57 \\
\hline $\begin{array}{l}\mathrm{GA}_{3} \mathbf{5 0}+\mathrm{CaCl}_{2} \mathbf{2 \%}+ \\
\mathrm{Zn} \mathrm{0.025 \%}\end{array}$ & 98.50 & 108.65 & 103 & 6.5 & 5.6 & 6.1 & 473.0 & 456.0 & 4645 & 65.31 & 64.50 & 65.40 \\
\hline $\begin{array}{l}\text { NAA } \quad 25+\mathrm{CaCl}_{2} \quad 2 \% \\
+\mathrm{Zn} 0.025 \%\end{array}$ & 70 & 10 & 100.77 & 6.8 & 5.9 & 6.4 & 4 & .0 & .5 & 33 & 11 & .97 \\
\hline N. LSD & 4.98 & 5.96 & & 0.38 & $\mathbf{0 . 3 3}$ & & 22.18 & 23.96 & & 3.31 & 2.86 & \\
\hline
\end{tabular}


Table 2. Effect of $\mathrm{GA}_{3}$, NAA, calcium chloride and $\mathrm{Zn}$ spraying on fruit dimension (cm) and juice \% of Manfalouty pomegranate fruits during 2017 and 2018 seasons.

\begin{tabular}{|c|c|c|c|c|c|c|c|c|c|}
\hline \multirow[t]{2}{*}{ Treatment } & \multicolumn{3}{|c|}{$\begin{array}{l}\text { Fruit length } \\
(\mathrm{cm})\end{array}$} & \multicolumn{3}{|c|}{$\begin{array}{l}\text { Fruit dimension } \\
\text { (cm) }\end{array}$} & \multicolumn{3}{|c|}{ Juice (\%) } \\
\hline & 2017 & 2018 & Mean & 2017 & 2018 & Mean & 2017 & 2018 & Mean \\
\hline \begin{tabular}{|l|} 
Control \\
\end{tabular} & 8.08 & 7.89 & 7.98 & 9.20 & 8.38 & 8.79 & 40.66 & 41.14 & 0.83 \\
\hline $\mathrm{GA}_{3} \mathbf{5 0} \mathrm{pp}$ & .10 & 8.86 & 8.98 & 10.12 & 9.11 & 62 & 49.30 & & \\
\hline ppm & 8.89 & 8.65 & 8.77 & 10.08 & 9.02 & 55 & 45.20 & 46.20 & 45.70 \\
\hline NAA 25 ppm & 8.41 & 8.24 & 8.32 & 9.60 & 8.76 & 18 & 44.30 & 45.89 & 5.09 \\
\hline NAA 50 ppm & 8.46 & 8.20 & 8.33 & 9.64 & 8.80 & 9.22 & 47.75 & 48.57 & 48.16 \\
\hline CaCl 2\% & 8.70 & 8.61 & 8.66 & 9.94 & 9.10 & 9.52 & 49.90 & 50.10 & 50.00 \\
\hline $\mathrm{CaCl} 4 \%$ & 8.62 & 8.43 & 8.52 & 9.86 & 8.94 & 9.40 & 49.66 & 50.15 & 49.90 \\
\hline Zn $0.025 \%$ & 8.40 & 8.22 & 8.31 & 9.61 & 8.78 & 9.20 & 51.10 & 50.86 & 50.98 \\
\hline Zn 0.050\% & 8.43 & 8.28 & 8.36 & 9.65 & 8.83 & 9.24 & 51.00 & 51.03 & 51.01 \\
\hline $\mathrm{GA}_{3} 50+\mathrm{CaCl}_{2} 2 \%+\mathrm{Zn} 0.025 \%$ & 8.92 & 8.75 & 8.83 & 10.18 & 9.28 & 9.73 & 50.99 & 50.90 & 50.94 \\
\hline $\begin{array}{l}\text { NAA } 25+\mathrm{CaCl}_{2} 2 \% \quad+\quad \mathbf{Z n} \\
0.025 \%\end{array}$ & 8.78 & 8.59 & 8.68 & 10.00 & 9.11 & 9.55 & 50.82 & 50.78 & 50.80 \\
\hline N. LSD & 0.31 & 0.29 & & 0.38 & 0.36 & & 2.91 & 3.15 & \\
\hline
\end{tabular}

The recorded fruit weight were (456.2, 452.9, 405.5, 406.4, 444.9, $448.6,418.5,420.8,464.5,435.5$ and $370.8 \mathrm{~g}$ as an av. of the two studied seasons) due to spray with $\mathrm{GA}_{3}$ at 50 ppm, $\mathrm{GA}_{3}$ at $75 \mathrm{ppm}, \mathrm{NAA} 25 \mathrm{ppm}$, NAA 50 ppm, $\mathrm{CaCl}_{2} 2 \%, \mathrm{CaCl}_{2} 4 \%$, Zn $0.025 \%$, Zn $0.050 \%, \mathrm{GA}_{3} 50$ ppm combined with $\mathrm{CaCl} 2 \%$ plus $\mathrm{Zn}$ $0.025 \%$, NAA $25 \mathrm{ppm}$ combined $\mathrm{CaCl}_{2} 2 \%$ plus $\mathrm{Zn} 0.025 \%$ and unsprayed one, respectively. Hence, corresponding the increment percentage of fruit weight over unsprayed ones were $(23.03,22.14,9.36,9.60$, $19.98,20.98,12.86,13.48,25.27$ and $17.30 \%$ ), respectively.

\section{B- Chemical fruit constituents:}

Data presented in Tables (3 \& 4) indicated that all spraying, excepted $\mathrm{GA}_{3}$ singly significantly improved the fruit chemical constituents in terms of increasing the total soluble solids, reducing sugars, anthocyanin contents and reducing, the tannins contents and total acidity percentage compared to unsprayed ones. On the other hand, spraying $\mathrm{GA}_{3}$ either at 50 or $75 \mathrm{ppm}$ significantly decreased the total soluble solids, reducing sugars, and anthocyanin content compared to unsprayed ones. All treatments significantly increased vitamin $\mathrm{C}$ compared to unsprayed ones.

The highest values of TSS (16.23 \& 16.32\%), reducing sugar (12.96 \& 12.99\%), and anthocyanin content (61.55 \& $62.74 \mathrm{mg} / 100 \mathrm{~g})$ and V.C. contents (27.24 \& 26.96 $\mathrm{mg} / 100 \mathrm{ml}$ as an av. of the two studied seasons) were recorded due to spray by combined of $\mathrm{GA}_{3} 50 \mathrm{ppm}$ plus $\mathrm{CaCl}_{2} 2 \%$ and $\mathrm{Zn} 0.025 \%$ and NAA $25 \%$ ppm plus $\mathrm{CaCl}_{2} 2 \%$ and Zn $0.025 \%$ ), respectively. These values were $(15.16,10.84,55.89$ and 23.84) due unsprayed ones, respectively. Hence, the corresponding increment percentage of these traits due to spray $\mathrm{GA}_{3}$ or NAA combined with $\mathrm{CaCl}_{2} 2 \%$ and $\mathrm{Zn} 0.025 \%$ over unsprayed ones were attained (7.06 \& 7.65\%), (19.56 \& 19.83\%), (10.13\& $12.26 \%)$ and $(14.26 \& 13.09 \%)$, respectively. 
Table 3. Effect of $\mathrm{GA}_{3}$, NAA, calcium chloride and $\mathrm{Zn}$ spraying on TSS (\%), reducing sugars (\%) and Acidity (\%) of Manfalouty pomegranate juice during 2017 and 2018 seasons.

\begin{tabular}{|c|c|c|c|c|c|c|c|c|c|}
\hline \multirow[b]{2}{*}{ Treatment } & \multicolumn{3}{|c|}{ TSS (\%) } & \multicolumn{3}{|c|}{ Reducing sugars (\%) } & \multicolumn{3}{|c|}{ Acidity (\%) } \\
\hline & 2017 & 2018 & Mean & 2017 & 2018 & Mean & 2017 & 2018 & Mean \\
\hline Control & 15.12 & 15.00 & 15.16 & 10.73 & $10 . .95$ & 10.84 & 1.30 & 1.39 & 1.35 \\
\hline $\mathrm{GA}_{3} 50 \mathrm{ppm}$ & 14.80 & 14.75 & 14.78 & 10.38 & 10.22 & 10.30 & 0.93 & 0.99 & 0.96 \\
\hline $\mathrm{GA}_{3} 75 \mathrm{ppm}$ & 14.63 & 14.58 & 14.61 & 10.38 & 10.35 & 10.37 & 0.98 & 0.98 & 0.98 \\
\hline NAA 25 ppm & 15.76 & 15.82 & 15.79 & 12.61 & 12.36 & 12.48 & 0.89 & 0.96 & 0.92 \\
\hline NAA $50 \mathrm{ppm}$ & 16.18 & 16.10 & 16.14 & 12.48 & 12.49 & 12.49 & 0.93 & 0.99 & 0.96 \\
\hline $\mathrm{CaCl} 2 \%$ & 16.20 & 16.15 & 16.18 & 12.61 & 12.36 & 12.48 & 0.98 & 1.02 & 1.00 \\
\hline $\mathrm{CaCl} 4 \%$ & 16.25 & 16.08 & 16.17 & 12.95 & 12.94 & 12.94 & 0.97 & 1.04 & 1.01 \\
\hline Zn $0.025 \%$ & 16.00 & 16.12 & 16.06 & 12.88 & 12.84 & 12.86 & 0.98 & 1.05 & 1.01 \\
\hline Zn $0.050 \%$ & 16.10 & 16.18 & 16.14 & 12.84 & 12.85 & 12.85 & 0.95 & 1.02 & 0.99 \\
\hline $\begin{array}{l}\mathbf{G A}_{\mathbf{3}} \mathbf{5 0}+\mathrm{CaCl}_{2} \mathbf{2 \%} \\
+\mathrm{Zn} \mathrm{0.025 \%} \\
\end{array}$ & 16.15 & 16.32 & 16.32 & 12.97 & 12.95 & 12.96 & 0.98 & 1.05 & 0.98 \\
\hline $\begin{array}{l}\text { NAA } \quad 25+\mathrm{CaCl}_{2} \\
2 \%+\mathrm{Zn} \mathbf{0 . 0 2 5 \%}\end{array}$ & 16.38 & 16.25 & 16.32 & 12.97 & 13.02 & 12.99 & 0.90 & 0.95 & 0.92 \\
\hline N. LSD & $\mathbf{0 . 5 3}$ & 0.48 & & 0.51 & 0.46 & & 0.31 & 0.26 & \\
\hline
\end{tabular}

Table 4. Effect of $\mathrm{GA}_{3}$, NAA, calcium chloride and $\mathrm{Zn}$ spraying on VC, Anthocyanin $(\mathrm{mg} / 100 \mathrm{~g})$ and tannin content $(\mathrm{mg} / 100 \mathrm{ml}$ of juice) of Manfalouty pomegranate juice during 2017 and 2018 seasons.

\begin{tabular}{|c|c|c|c|c|c|c|c|c|c|}
\hline \multirow[t]{2}{*}{ Treatment } & \multicolumn{3}{|c|}{ VC } & \multicolumn{3}{|c|}{ Anthocyanin (mg/100 g) } & \multicolumn{3}{|c|}{$\begin{array}{c}\text { Tannins content (mg/100 } \\
\text { ml of juice) }\end{array}$} \\
\hline & 2017 & 2018 & Mean & 2017 & 2018 & Mean & 2017 & 2018 & Mean \\
\hline Control & 24.16 & 23.84 & 24.00 & 54.80 & 56.98 & 55.89 & 2.69 & 2.77 & 2.73 \\
\hline $\mathbf{G A}_{3} \mathbf{5 0} \mathbf{~ p p m}$ & 27.32 & 28.27 & 27.79 & 51.58 & 54.31 & 52.94 & 2.73 & 2.78 & 2.76 \\
\hline $\mathrm{GA}_{3} 75 \mathrm{ppm}$ & 26.78 & 27.83 & 27.30 & 50.64 & 54.68 & 52.66 & 2.68 & 2.86 & 2.77 \\
\hline NAA 25 ppm & 25.68 & 26.18 & 25.93 & 60.28 & 62.78 & 61.53 & 2.24 & 2.39 & 2.40 \\
\hline NAA 50 ppm & 25.84 & 25.94 & 25.89 & 59.89 & 69.11 & 61.50 & 2.17 & 2.41 & 2.29 \\
\hline CaCl 2\% & 26.16 & 26.88 & 26.52 & 59.68 & 63.00 & 61.34 & 2.14 & 2.46 & 2.30 \\
\hline $\mathrm{CaCl} 4 \%$ & 26.54 & 27.11 & 26.82 & 60.11 & 63.43 & 61.77 & 2.21 & 2.40 & 2.31 \\
\hline Zn $0.025 \%$ & 25.90 & 26.18 & 26.04 & 60.13 & 62.88 & 61.51 & 2.13 & 2.43 & 2.28 \\
\hline Zn $0.050 \%$ & 26.11 & 27.06 & 26.59 & 60.36 & 63.11 & 61.73 & 2.24 & 2.51 & 2.38 \\
\hline $\begin{array}{l}\mathrm{GA}_{3} 50+\mathrm{CaCl}_{2} 2 \% \\
+\mathrm{Zn} 0.025 \% \\
\end{array}$ & 26.95 & 27.53 & 27.24 & 60.65 & 62.45 & 61.55 & 2.18 & 2.34 & 2.26 \\
\hline $\begin{array}{lr}\mathrm{NAA} & \mathbf{2 5}+\mathrm{CaCl}_{2} \\
2 \% & \mathrm{Zn} \mathbf{0 . 0 2 5} \%\end{array}$ & 26.84 & 27.08 & 26.96 & 61 & 63.66 & 62 & 2.11 & 2.35 & 2.23 \\
\hline N. LSD & 1.43 & 1.15 & & 1.98 & 2.01 & & 0.14 & 0.19 & \\
\hline
\end{tabular}

The least values of acidity were $(0.92 \& 0.98 \%)$ and tannin content (2.26 \& $2.23 \mathrm{mg} / 100 \mathrm{ml} \mathrm{g}$ juice) as an av. of the two studied seasons) due to spray $\mathrm{GA}_{3} 50$ ppm combined, with $\mathrm{CaCl}_{2} 2 \%$ plus $\mathrm{Zn} 0.025 \%$ and NAA 25 ppm plus $\mathrm{CaCl}_{2} 2 \%$ and $\mathrm{Zn}$ $0.05 \%$, respectively.

On other hand, the highest values of acidity $(1.35 \%)$ and tannins content $(2.73 \mathrm{mg} / 100 \mathrm{ml})$ as an av. of the two studied seasons, respectively. Hence, the corresponding decrement percentage of those traits attained $(31.85 \& 27.41 \%)$ and $(17.22 \&$ $18.32 \%$ ), respectively.

\section{Discussion}

The effect of $\mathrm{CaCl}_{2}$ on reducing the fruit cracking percentage may be attributed to that calcium enhanced 
fruit growth and cause maintaining of water balance between exocarp and inside fruit tissues and keep fruits cell walls flexibility and strength. Positive role of auxins like NAA and $\mathrm{GA}_{3}$ application on fruit weight and yield weight may be explained from the fact that there are associated with cell division and cell enlargement (Weaver, 1972). In addition, they play a modulation role in mobilization of nutrient to the developing organs (Suman et al., 2017). $\mathrm{GA}_{3}$ an influence fruit cracking indirectly by influencing of permeability or elasticity of the fruit cuticle (El-Salhy, 1996; Hegazi et al., 2014 and Bakeer, 2016).

These results are agree with those reported by El-Salhy (1996), Mohamed (2004), Ali (2006), Hasani et al. (2012), Reddy and Prasad (2012),Sheikh and Manjula (2012), Goswami et al. (2013) Ahmed et al. (2014), Bakeer (2016), Digrase et al. (2016), El-Akkad et al. (2016) and Masoud et al. (2018).

Zinc plays a great role in plant growth, yield and fruit quality as a result of affecting many physiological processes in plant life and activating a large number of enzymes, nucleic acid metabolism and protein biosynthesis (Swietlik, 1999 and Hasani et al. (2012)).

Gibberellins are involved in cell division and cell elongation, resulted in influence fruit weight and size. On the other hand, calcium enhanced fruit growth and cause maintaining of water balance. These effects induce an obvious promotion increasing in yield fruit weights and their dimension and their juice contents.
The data of the current study, the foliar application of combined of $\mathrm{GA}_{3}$ or NAA plus $\mathrm{CaCl}_{2}$ and $\mathrm{ZnSO}_{4}$ caused about (23.21 \& 19.86\%), (25.30\& 17.46\%), (7.06 \& 7.65\%), $(11.12 \& 12.87 \%)$ and (14.26 \& $13.09 \%$ ) increases in the yield, fruit weight and TSS as well as, anthocyanin and V.C contents.

These results were supported by the results of El-Salhy (1996), Mohamed (2004), Ali (2006), ElHamedawy et al. (2008), Ghosh et al. (2009), Reddy and Prasad (2012), Hasani et al. (2012), Eiada and AlHadethi (2013), Verreynne and Merwe (2011), Hegazi et al. (2014), Masoud et al. (2018) and Thakur and Sharma (2018).

\section{Conclusion}

On the light at previously results, it could be concluded that sprayed the Manfalouty pomegranate trees with calcium chloride at $2 \%$ and Zinc sulphate at $0.025 \%$ combined $\mathrm{GA}_{3}$ at $50 \mathrm{ppm}$ or NAA 25 ppm three times to get high yield and reduction fruit cracking percentage with fruit quality.

\section{References}

Ahmed, F.F.; M.M. Mohamed; A.M.A. Abou El-Kashab and S.H.A Aeed (2014). Controlling fruit splitting and improving productivity of Manfalouty pomegranate trees by using salicylic acid and some nutrients. World Rural Observ., 6 (1): 87-93.

Ali, M.A.A. (2006). Effect of some treatments on improving pomegranate fruit quality. Ph.D. Thesis, Agricultural Science (Pomology), Faculty of Agriculture, Cairo University.

Anawal, V.V.; P. Narayanaswamy and S.D. Ekabate (2016). Effects of plant regulators on fruit-set and 
yield of pomegranate $\mathrm{e}$ cv. Bhagwa. In. J. of Current Res. 8: 2908-2910.

Association of Official Agricultural Chemists (1995). Official Methods of Analysis. A.O.A.C. $14^{\text {th }}$ Ed. Published by A.O.A.C. Washington, D.C., U.S.A..

Bahadur, L.; C.S. Malhi and Z. Singh (1998). Effect of foliar and soil application of zinc sulphate on zinc uptake, tree size, yield and fruit quality of mango. J. Plant Nutr., 21 (3): 589-600.

Bakeer, S.M. (2016). Effect of ammonium nitrate fertilizer and calcium chloride foliar spray on fruit cracking and sunburn of Manfalouty pomegranate trees. Scientia Horticulturae, 209: 300-308.

Bambal, S.B.; K.N. Wavhal and S.D. Nasolkar (1991). Effect of foliar application of micro-nutrients on fruit quality and yield of pomegranate (Punica granatum L. cv. Ganesh). Maharashtra J. of Hortic., 5 (2): 32-36.

Cam, M. and Y. Hisil (2010). Pressurized water extraction of polyphenols from pomegranate peels. Food Chem., 123 (3): 878-885.

Thakur, Ch. And C.L. Sharma (2018). Effect of plant growth regulators on physico-chemical parameters of pomegranate (Punica granatum L.) cv. Kandhari. In. J. of Chemical Studies, 6 (4): 1849-1855.

Cheour, F.; C. Willemot; J. Arul; Y. Desjardins; J. Makhlouf; P.M. Charest and A. Gosselim (1990). Foliar application of calcium chloride delays postharvest ripening strawberry. J.A.M. Soc. Hortic. Sci., 115: 789-792.

Digrase, S.S.; T.B. Tambe; A.S. Kadam and B.M. Kalalband (2016). Effect of different plant growth regulators and chemicals on growth and yield of pomegranate (Punica granatum
L.) cv. Bhagwa. Adv. Res. Crop Improv., 7 (1) June: 96-99, Hind Agr. Res. and Training Institute.

Eiada, A.O. and M.A. Al-Hadethi (2013). Effect of foliar application with Manganese and zinc on pomegranate growth, yield and fruit quality. J. Hortic. Sci. \& Ornam. Plants, 5 (1): 41-45.

El-Akkad, M.M.; Fatma El-Zahraa M. Gouda and R.A. Ibrahim (2016). Effect of $\mathrm{GA}_{3}$, calcium chloride and vapor guard spraying on yield and fruit quality of Manfalouty pomegranate trees. Assiut J. Agric. Sci., 48 (6-1): 181-190.

El-Hamedawy, A.M.S.; L.L.A. ElHassnawy and S.K.H. Krof (2008). Effect of NNA and vapor guard spraying on infection percentage disease and quality characters of local pomegranate (Punica granatum L.) after storage. Scientific Journal of Karbalaa University, 6 (1): 210-215.

El-Salhy, A.M. (1996). Performance of single and multiple Manfalouty pomegranate fruits in response to $\mathrm{GA}_{3}$ application. $4^{\text {th }}$ Arabic Conf. for Horti Crops, El-Minia, Egypt, 757-767.

Goswami, J.D.; N.M. Patel; H.S. Bhadauria and V.R. Wankhade (2013). Effect of plant growth substance on growth, fruit setting and yield of pomegranate cv. Sinduri. J. of Agri. Sci., 9 (1): 332-334.

Ghosh, S.N.; B. Bera; S. Roy and A. Kundu (2009). Effect of plant growth regulators in yield and fruit quality in pomegranate cv. Ruby. J. Hort. Sci., 4 (2): 158-160.

Gil, M.I.; F.A. Tomas-Barberan; B. Hass-Pierce; D.M. Holcroft and A.A. Kader (2000). Antioxidant activity of pomegranate juice and its relationship with phenolic composition and processing. J. Agric. Food Chem., 48: 4581-4589. 
Hasani, M.; Z. Zamani; G. Savaghebi and R. Fatahi (2012). Effect of zinc and manganese as foliar spray on pomegranate yield, fruit quality and leaf minerals. J. of Soil Sci. and Plant Nutrition, 12 (3): 471480.

Hegazi, A.; N.R. Samra; E.E.T. El-Baz; Bahan M. Khalil and M.S. Gawish (2014). Improving fruit quality of Manfalouty and Wonderfull pomegranates by using bagging and some spray treatments with gibberellic acid, calcium chloride and kaolin. J. Plant Production, Mansoura Univ., 5 (5): 779-792.

Khalil, H.A. and H.S.H. Aly (2013). Cracking and fruit quality of pomegranate (Punica granatum L.) as affected by pre-harvest sprays of some growth regulators and mineral nutrients. J. Hortic. Sci. \& Ornam. Plants, 5 (2): 71-76.

M.A.L.R. (2016). Ministry of Agriculture and Land Reclamation Economic. Affairs Sector Bull., Agric. Statistics.

Masoud, A.A.B.; E.M.A. Radwan and Eman, A.A. Abou-Zaid (2018). Effect of some micro-nutrient, silicon and $\mathrm{GA}_{3}$ spraying on yield and fruit quality of pomegranate. Assiut J. Agric. Sci., 49 (3): 97-106.

Mitra, S.K. (1997). Post harvest physiology and storage of tropical and sub-tropical fruits. CAB, INT., Nadia, West Bengal, India, pp. 84122.

Mohamed, A.K.A. (2004). Effect of gibberellic acid $\left(\mathrm{GA}_{3}\right)$ and benzyladinine (BA) on splitting and quality of Manfalouty pomegranate fruits. Assiut J. Agric. Sci., 35 (3): 11-21.

Pooviah, B.W. (1979). Role of calcium in ripening and senescence. Common. Soil Sci. Plant Anal., 10: 8388 .
Rabino, I. and A.L. Mancinelli (1986). Light, temperature and anthocyanin production. J. Plant Physiol., 81 (3): 922-924.

Reddy, P.A. and D.M. Prasad (2012). Effect of plant growth regulators on fruit characters and yield of pomegranate (Punica granatum L.) cv. Genesh. Inter. J. Plant, Animal and Environmental Sci., 2: 91-93

Sepahi, A. (1986). GA 3 concentration for controlling fruit cracking in pomegranate. Iran Agric. Res., 5: 93-99.

Sheikh, M.K. and N. Manjula (2012). Effect of chemicals on control of fruit cracking in pomegranate $(\mathrm{Pu}$ nica granatum L.) var. Genesh. IIInternational symposium on the pomegranate, Zaragoza. CIHEAM/ Universidal Miguel Henández, p. 133-135.

Singh, D.B. (2004). Screening of pomegranate (Punica granatum L.) cultivars for arid ecosystem. Indian J. of Hortic. Sci. 74: 604-606.

Snedecor, G.W. and W.G. Cochran (1972). Statistical Methods, $6^{\text {th }}$ Ed. The Iowa State University Press, Ames, Iowa, U.S.A.

Suman, M.D.; P. Sangmu; D.R. Meghawal and O.P. Sahu (2017). Effect of plant growth regulators on fruit crops. J. of Pharmacognosy and Phytochemistry, 6 (2): 331-337.

Swietlik, D, (1999). Zinc nutrition and horticultural crops. Hort. Reviews John Wiley \& Sons Inc. New York, 23: 109-180.

Verreynn,S and S.V. Merwe (2011). Sunburn reduction on (Miho Wase) Satsuma mandarin. South Africa Fruit Journal, April/May 2011: 52-55.

Weaver, R.Z. (1972). Biological effects and mechanism of action. In: plant growth substances in agriculture, S. Chand and Company Ltd. Rm Ngar, New Delhi 110055, pp. 90117. 
تأثير رش حمض الجبريليك وحامض النفتالين و الكالسيوم والزنك علي إثمار أثجار الرمان المنقلوطي

علاء عبد الجابر بدوي مسعود، أسامة عبد الله علي خضير وفاطمة الزهر اء محمد عبد الله جودة

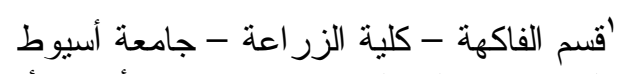

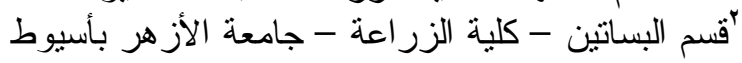

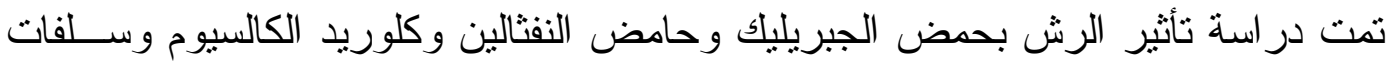

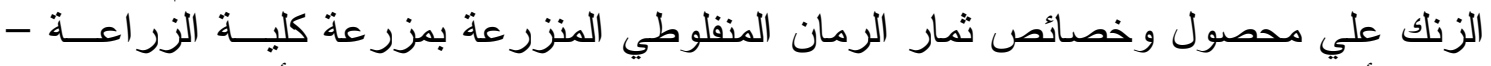

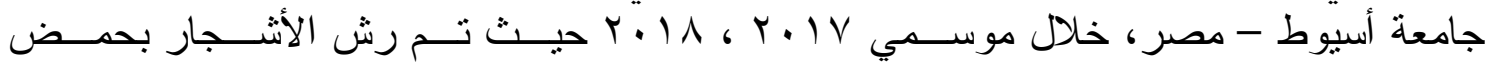

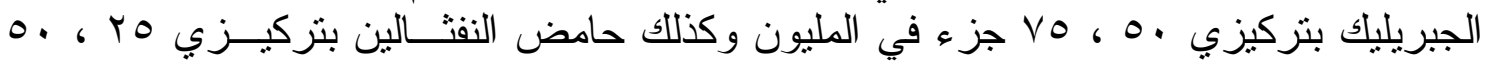

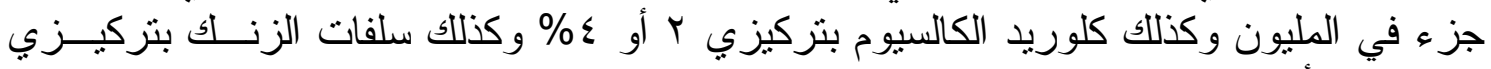

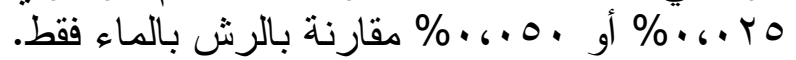

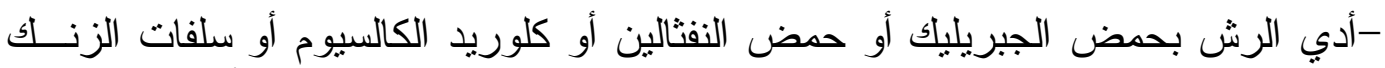

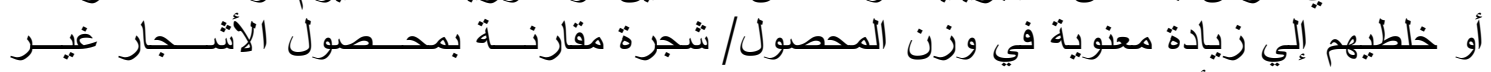

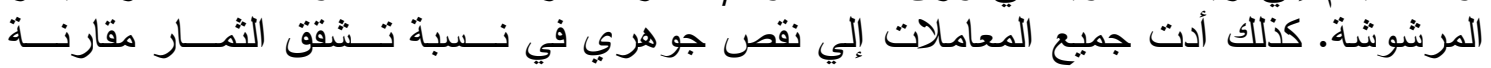
بالأثجار الغير مرشوشة.

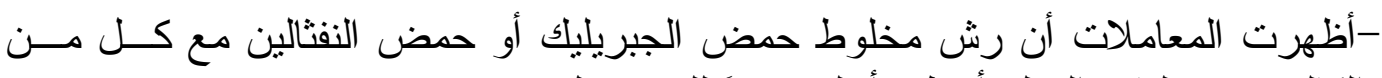

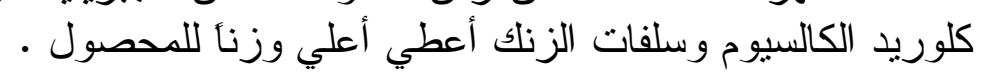

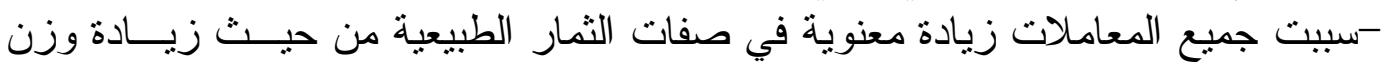
و أبعاد الثمار وكذلك نسبة اللب وحجم العصبر مقارنة فيلة بالثمار الغير معاملة.

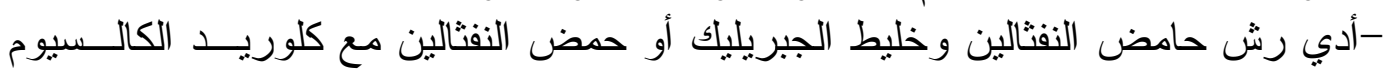

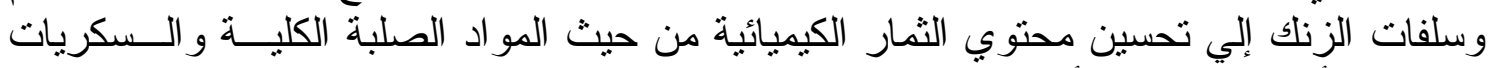

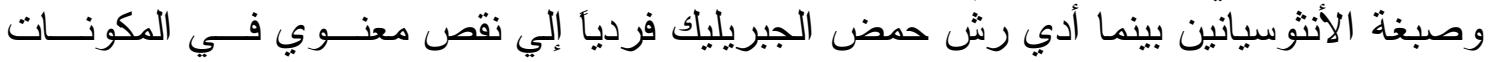

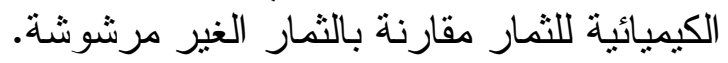

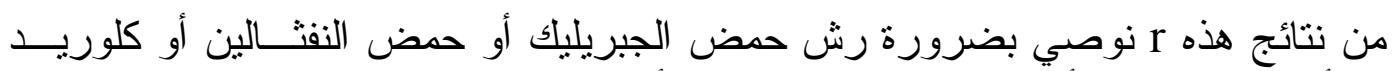

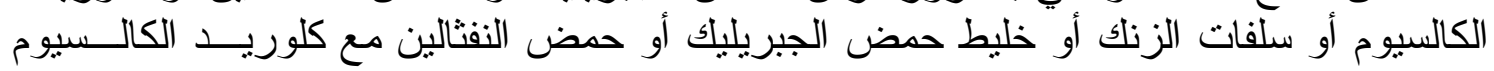

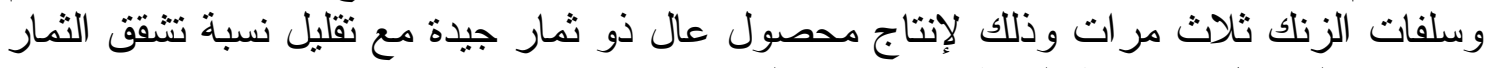
وهي من المشاكل الإنتاجية الهامة في بساتين الرمان. 